\title{
Supplemental barley and charcoal increase intake of sage- brush by lambs
}

\author{
R.E. BANNER, J. ROGOSIC, E.A. BURRITT, AND F.D. PROVENZA
}

Authors are associate professor, professor, research Associate, and Professor, Respectively Department of Rangeland Resources, Utah State University, Logan, Utah, U.S.A. 84322-5230. J. Rogosic is with the Institute for Adriatic Crops and Karst Reclamation, Put Duilova, 21000 Split, Croatia.

\begin{abstract}
We evaluated the influence of supplemental barley and activated charcoal on the intake of sagebrush by lambs in individual pens. In 3 experiments, lambs were fed sagebrush (harvested and chopped to $2-3 \mathrm{~cm}$ ) during the morning; they were fed a basal diet of alfalfa pellets in the afternoon. In the first experiment, lambs supplemented with activated charcoal + barley ate more A. tridentata ssp. vaseyana than lambs supplemented with barley ( 304 vs. $248 \mathrm{~g} ; P=.071$ ). A second set of experiments, which consisted of 3 trials, determined the effects of activated charcoal, barley, and subspecies of sagebrush on intake of sagebrush. Lambs supplemented with activated charcoal + barley ate more A. tridentata ssp. vaseyana (Trial 1; 292 vs. $225 \mathrm{~g} ; \mathrm{P}=\mathbf{0 8 8 6}$ ), and more A. tridentata ssp. tridentata (Trial 2; 371 vs. 255 g; $\mathbf{P}=\mathbf{. 0 3 1}$ ) than lambs supplemented with barley. In Trial 3, lambs supplemented with barley ate more sagebrush than lambs that were not supplemented (480 vs. $318 \mathrm{~g} ; \mathrm{P}=\mathbf{. 0 0 0 2}$ ). A third set of experiments compared activated charcoal + barley, barley, and no supplement in 2 trials. In Trial 1, lambs supplemented with activated charcoal + barley or barley generally ate more A. tridentata ssp. vaseyana than lambs not supplemented $(P=.017)$. In Trial 2 , lambs supplemented with activated charcoal + barley ate slightly more $A$. tridentata ssp. vaseyana than lambs supplemented with barley, and they ate substantially more than lambs not supplemented $(P=.032)$. Collectively, the results suggest that energy from supplemental barley increased intake of sagebrush by lambs fed a basal ration of alfalfa pellets which are high in protein, and that activated charcoal played a minor role in further increasing intake of sagebrush.
\end{abstract}

Key Words: sheep, macronutrients, terpenoids, rangeland

Sagebrush (Artemisia tridentata Nutt.) refers to a diverse array of subspecies and ecotypes of shrubs that occur on approximately 39 million hectares of land in the western United States (Bastian et al. 1995). While accounts vary, there is evidence that sagebrush has increased in abundance in many areas due to grazing preferences of herbivores and lack of fire.

Sagebrush steppe ecosystems are used in various ways, and one of the more important is as habitat for domestic and wild animals. Many grasses and forbs that grow with sagebrush are valuable

This research was supported by a grant from the Utah Agricultural Experiment Station. This paper is published as journal paper 7133, Utah Agricultural Experiment Station, Utah State Univ.

Manuscript accepted 26 Sept. 1999.

\section{Resumen}

Evaluamos la influencia de la suplementación de cebada y carbón activado en el consumo de "Sagebrush" por corderos confinados en corrales individuales. En 3 experimentos, los corderos se alimentaron con "Sagebrush" (cosechado y picado a 2-3 cm) durante la mañana y en la tarde se alimentaron con una dieta basal de pelets de alfalfa. En el primer experimento, los corderos suplementados con cebada + carbón activado comieron mas $\boldsymbol{A}$. tridentata ssp. vaseyana que los corderos suplementados con cebada (304 vs. $248 \mathrm{~g} ; \mathrm{P}=\mathbf{0 . 0 7 1}$ ). En un segundo grupo de exper imentos, consistente de 3 ensayos, se determinaron los efectos del carbón activado, cebada y subespecies de "Sagebrush" en el consumo de "Sagebrush." Los corderos suplementados con carbón activado + cebada comieron mas $A$. tridentata ssp. vaseyana (ensayo 1; 292 vs. 225 g $P=0.086)$ y más $A$. tridentata ssp. triden tata (ensayo 2; 371 vs. $255 \mathrm{~g} ; \mathbf{P}=\mathbf{0 . 0 3 1}$ ) que los corderos suplementados con cebada. En el experimento 3, los corderos suplementados con cebada comieron mas "Sagebrush" que los corderos sin suplementación (480 vs. $318 \mathrm{~g} ; \mathbf{P}=\mathbf{0 . 0 0 0 2})$. En un tercer grupo de experimentos, conformado de 2 ensayos, se comparo el carbón activado + cebada, cebada y sin suplemento. En el experimento 1 , los corderos suplementados con carbón activado + cebada o cebada generalmente comieron más $A$. tridentata ssp. vaseyana que los corderos sin suplementación $(P=0.017)$. En el ensayo 2, los corderos suplementados con carbón activado + cebada comieron un poco mas $A$. tridentata ssp. vaseyana que los corderos suplementados con cebada, y ellos comieron substancialmente mas que los corderos no suplementados $(P=\mathbf{0 . 0 3 2})$. Los resultados colectivos de este grupo de experimentos sugieren que la energía proveniente de la cebada suplementaria aumenta el consumo de "Sagebrush" de los corderos alimentados con una ración basal de pelets alfalfa los cuales son altos en proteína, y que el carbón activado jugo un papel menor en incrementar el consumo de "Sagebrush."

foods, but the merit of sagebrush as a forage varies. Although sagebrush is relatively high in nutrients for a rangeland shrub, some accessions of sagebrush are more digestible and nutritious than others (Welch and Pederson 1981, Welch and McArthur 1986). Different accessions also vary in kinds and amounts of potentially toxic compounds such as terpenes (Johnson et al. 1976, Personius et al. 1987), which can deter feeding by sheep, goats, cattle, mule deer, moose, hares, and voles (Picman 1986, Bray et al. 1991, Langenheim 1994). Thus, sagebrush is abundant and generally nutritious, but its forage value can be low because it contains a variety of terpenes, some of which deter feeding by herbivores. 
It may be possible to increase use of sagebrush with compounds like activated charcoal that adsorb terpenoids and other potentially harmful compounds that may occur in sagebrush, and with supplemental macronutrients that may facilitate detoxification. Activated charcoal is a safe, effective, and inexpensive gastrointestinal adsorbent recommended for use by virtually every textbook or handbook on the treatment of acute drug intoxications because it adsorbs a wide range of compounds such as alkaloids, phenols, salicylates, sulfanoamides, and inorganic compounds (Hayden and Comstock 1975, Levy 1982). Supplemental macronutrients may also increase use of sagebrush, as needs for energy and protein increase due to detoxification processes (Foley et al. 1995, Illius and Jessop 1995). Thus, we hypothesize that nutritious supplements containing macronutrients and adsorbents like activated charcoal, alleviate the adverse effects of the terpenoids in sagebrush, thereby allowing an increase in use of sagebrush by herbivores. Our objective was to evaluate the roles of supplemental barley and activated charcoal on the intake of sagebrush by lambs fed a basal diet of alfalfa pellets. We conducted 3 independent experiments over an 18-month period with different sets of animals.

\section{Materials and Methods}

\section{Experiment 1}

The objective of the first experiment was to determine the effects of activated charcoal + barley on intake of sagebrush by lambs. We fed sagebrush harvested in early May from the foothills west of Logan in northern Ut. Sagebrush leaves and twigs were clipped, placed in woven, polyethylene feed sacks, and frozen. Several days after freezing, the sagebrush was ground to $1 \mathrm{~cm}$ in length with a chipper, mixed for uniformity, placed in plastic bags in 8 to $10 \mathrm{~kg}$ amounts, and returned to a freezer. The night before each daily trial, a bag of sagebrush was removed from the freezer and placed in a refrigerator to thaw prior to the next day's feeding.

We accustomed 16 lambs (crossbreds; 4 mo age; $38 \mathrm{~kg} \mathrm{BW}$ ) from the Utah State University farm to eat a barley-activated charcoal mix and sagebrush prior to the trials. We determined the average intake of sagebrush for each lamb during hourlong trials when they were being fed a basal diet of alfalfa pellets, and ranked them from high to low based on their intake of sagebrush. We then assigned lambs at random to 2 treatments $(n=8$ lambs treatment ${ }^{-1}$ ), balanced for intake of sagebrush. Lambs in 1 group received activated charcoal + barley, whereas lambs in the other group received only a barley supplement.

At 0730 hours each morning on days 1 to 6 , treatment lambs received $100 \mathrm{~g}$ of ground barley mixed with $10 \mathrm{~g}$ of commercial grade activated charcoal, whereas controls were offered $100 \mathrm{~g}$ barley; all lambs consumed all of their supplement throughout the trial. Neither activated charcoal + barley nor barley supplements were fed on days 7 and 8 to determine if intake of lambs would decline. From 0800 to 0900 hours each day, lambs had access to ground sagebrush (A. tridentata Nutt. ssp. vaseyana (Rydb.) Beetle) ad libitum. Food refusals were collected and sagebrush intake was calculated. Lambs were then offered alfalfa pellets ad libitum until 1830 hours and held without food overnight. Lambs had free access to tracemineral salt blocks and water throughout the 8-day study.

\section{Experiment 2}

The objective of Experiment 2 was to determine the effects of supplemental barley and activated charcoal, as well as food restriction, on the intake of sagebrush. We conducted three trials with 24 lambs (crossbreds about 3 mo age) obtained from the U.S. Sheep Experiment Station. Lambs weighed $26 \mathrm{~kg}$ at the beginning of the experiment just prior to Trial 1 and $31 \mathrm{~kg}$ at the end of Trial 3 . We conditioned lambs to eat a barley-activated charcoal mix and sagebrush, as in Experiment 1, and we assigned lambs at random, balanced for intake of sagebrush, to 2 treatments $\left(n=12\right.$ treatment $\left.^{-1}\right)$, one that received the activated charcoal + barley supplement and the other that received only barley. Lambs remained in the same treatments in Trials 1 and 2 and were randomly re-assigned to treatments by pairs for Trial 3.

We used 2 subspecies of sagebrush. In Trial 1, we used A. tridentata ssp. vaseyana harvested in the foothills west of Logan in northern Utah. For Trial 2, we used A. tridentata Nutt. ssp. tridentata harvested in Tintic Valley in central Utah. For Trial 3, we used both subspecies of sagebrush. Sagebrush leaves and twigs were clipped, frozen, ground, and stored as in Experiment 1.

Trial 1. At 0800 hours daily, treatment lambs were fed $180 \mathrm{~g}$ of ground barley mixed with $20 \mathrm{~g}$ of activated charcoal, whereas controls were fed $180 \mathrm{~g}$ barley. From 0820 to 1200 hours, lambs were fed sagebrush (A. tridentata ssp. vaseyana) ad libitum. We determined intake of activated charcoal + barley and sagebrush for each lamb for 13 days; all lambs ate all of their supplement throughout the trial. At 1200 hours, lambs were fed alfalfa pellets at $80 \%$ of maintenance. Lambs had free access to trace-mineral blocks and water for the duration of the trial.

Trial 2. The procedures for this trial were the same as those described for Trial 1 , except that lambs were offered a different subspecies of sagebrush (A. tridentata ssp. tridentata), and the trial lasted 7 days. Again, all lambs ate all of their supplement-activated charcoal + barley or barley-during the trial.

Trial 3. The methods for this trial were the same as those for Trial 1, except treatment lambs received $200 \mathrm{~g}$ of ground barley and controls received no barley. Lambs were ranked from high to low, based on sagebrush intake in Trials 1 and 2 , and then assigned to treatments. Half of the lambs previously fed activated charcoal + barley in Trials 1 and 2 were fed barley in this trial, whereas the other half were not fed barley. Likewise, half of the lambs previously fed barley received barley, whereas the other half did not receive barley. Lambs ate all of the barley during the trial. On days 1 to 3 lambs had access to $A$. tridentata ssp. tridentata, whereas on days 4 to 11 they had access to A. triden tata ssp. vaseyana. Sagebrush was available ad libitum from 0820 to 1200 hours daily.

\section{Experiment 3}

Our objective was to compare 3 treatments - activated charcoal + barley vs. barley vs. no supplement - and to vary the level of food deprivation. Lambs (30 crossbreds, about 6 mo age; $45 \mathrm{~kg} \mathrm{BW}$ ) were adapted to supplements and sagebrush prior to the experiment, and they were ranked and assigned to treatments as in Experiments 1 and 2. Sagebrush (A. tri dentata ssp. vaseyana) was harvested, ground, and stored as in Experiments 1 and 2.

Trial 1. The objective of this trial was to compare intake of sagebrush by lambs when they had ad libitum access to alfalfa pellets for an extended period of time during the afternoon. At 0700 hours for 6 days, lambs $\left(n=10\right.$ treatment $\left.^{-1}\right)$ were offered activated charcoal + barley $(25 \mathrm{~g}+$ $225 \mathrm{~g}$ ), barley (225 g), or no supplement for $20 \mathrm{~min}$. All lambs consumed all of the supplement. Lambs were then given 
access to sagebrush ad libitum from 0720 to 1200 hours. Lambs had access to alfalfa pellets ad libitum from 1200 to 1700 hours each afternoon.

Trial 2. The objective of Trial 2 was to determine if food restriction influenced the effect of supplementation on intake of sagebrush by lambs. For 2 days following Trial 1, lambs had access to alfalfa pellets until food boxes were removed at 1400 hours, and lambs were fasted overnight. At 0900 hours for the next 4 days, lambs were offered activated charcoal + barley $(25 \mathrm{~g}+$ $225 \mathrm{~g}$ ), barley (225 g), or no supplement for $20 \mathrm{~min}$; lambs were in the same treatments as for Trial 1. All lambs ate all of the supplement offered. Lambs were then given access to sagebrush ad libitum from 0920 to 1300 hours. Lambs had access ad libitum to alfalfa pellets for 1 hour each afternoon, from 1300 to 1400 hours.

\section{Statistical Analyses}

The analyses of variance had 2 treatments (activated charcoal + barley, barley) in Experiment 1 and in Experiment 2,

Fig. 1. Intake (means \pm SE) of Artemisia tridentata ssp. vaseyana for 1 hour day ${ }^{-1}$ by lambs $^{2}$ Trials 1 and 2. The analyses of variance had 2 treatments in Experiment 2, Trial 3 (barley, no supplement) and 3 treatments (activated charcoal + barley, barley, no supplement) in Experiment 3. Lambs within treatment was the error term for treatments. Day was the repeated measure. Lamb within treatment $x$ day was the error term for day and its interaction with treatment.

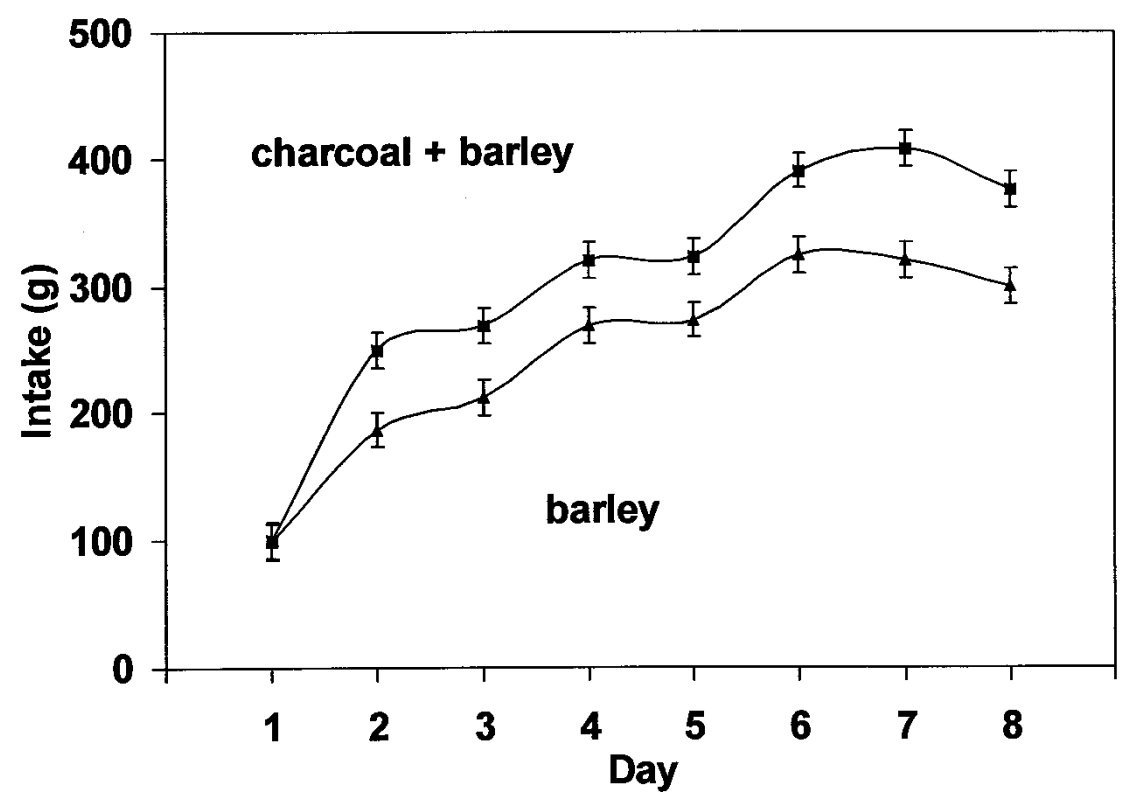
supplemented with activated charcoal + barley or barley alone (L.S.D. $.05=29)$. Barley and charcoal were fed from days 1 to 6 , but not on days 7 or 8 .

\section{Results}

\section{Experiment 1}

Lambs supplemented with activated charcoal + barley ate more $A$. tridentata ssp. vaseyana than lambs supplemented with barley (304 vs. $248 \mathrm{~g}$; P = .071; Fig. 1). Lambs increased intake of sagebrush during the trial $(\mathrm{P}=.0001)$. Treatment and day did not interact $(\mathrm{P}=.148)$.

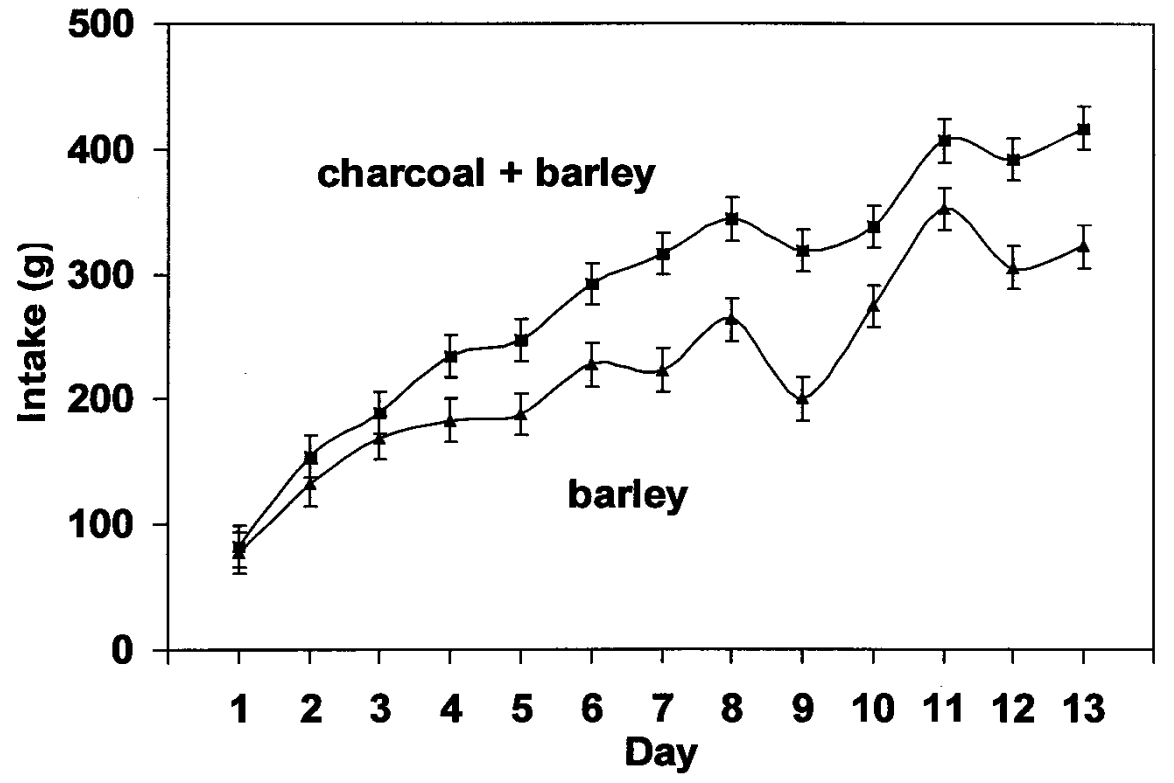

Fig. 2. Intake (means \pm SE) of Artemisia tridentata ssp. vaseyana for 4 hours day $^{-1}$ by lambs supplemented with activated charcoal + barley or barley alone $($ L.S.D. $05=35)$.

When supplements were withheld on days 7 and 8, lambs accustomed to eating the activated charcoal + barley supplement did not continue to increase intake of sagebrush on day 7 , as they had on days 1 to 6 , and they decreased intake on day 8 (390 vs. 407 vs. $375 \mathrm{~g}$ for days $6,7,8$; L.S.D .05 $=29)$. Lambs accustomed to receiving the barley supplement did not increase intake of sagebrush on days 7 and 8 , as they had on days 1 to $6(324$ vs. 320 vs. $299 \mathrm{~g}$ for days $6,7,8$; L.S.D $.05=29$ ).

\section{Experiment 2}

Trial 1. Lambs supplemented with activated charcoal + barley ate more A. triden tata ssp. vaseyana than lambs supplemented with barley (292 vs. $225 \mathrm{~g}$; P = .086; Fig. 2). Lambs increased intake of sagebrush throughout the trial $(\mathrm{P}=.0001)$, and treatment and day interacted $(\mathrm{P}=.038)$.

Trial 2. Lambs supplemented with activated charcoal + barley ate more $A$. triden tata ssp. tridentata than lambs supplemented with barley (371 vs. $255 \mathrm{~g}$; $\mathrm{P}=$ .031; Fig. 3). Lambs increased intake of sagebrush during the trial $(\mathrm{P}=.0001)$. Treatment and day did not interact $(\mathrm{P}=$ $.552)$.

Trial 3. Lambs supplemented with barley ate more sagebrush than lambs that were not supplemented (480 vs. $318 \mathrm{~g} ; \mathrm{P}=$ .0002; Fig. 4). Lambs generally increased intake of sagebrush throughout the trial ( $\mathrm{P}$ $=.0001)$, and there was a treatment $\mathrm{x}$ day interaction $(\mathrm{P}=.0001)$. 


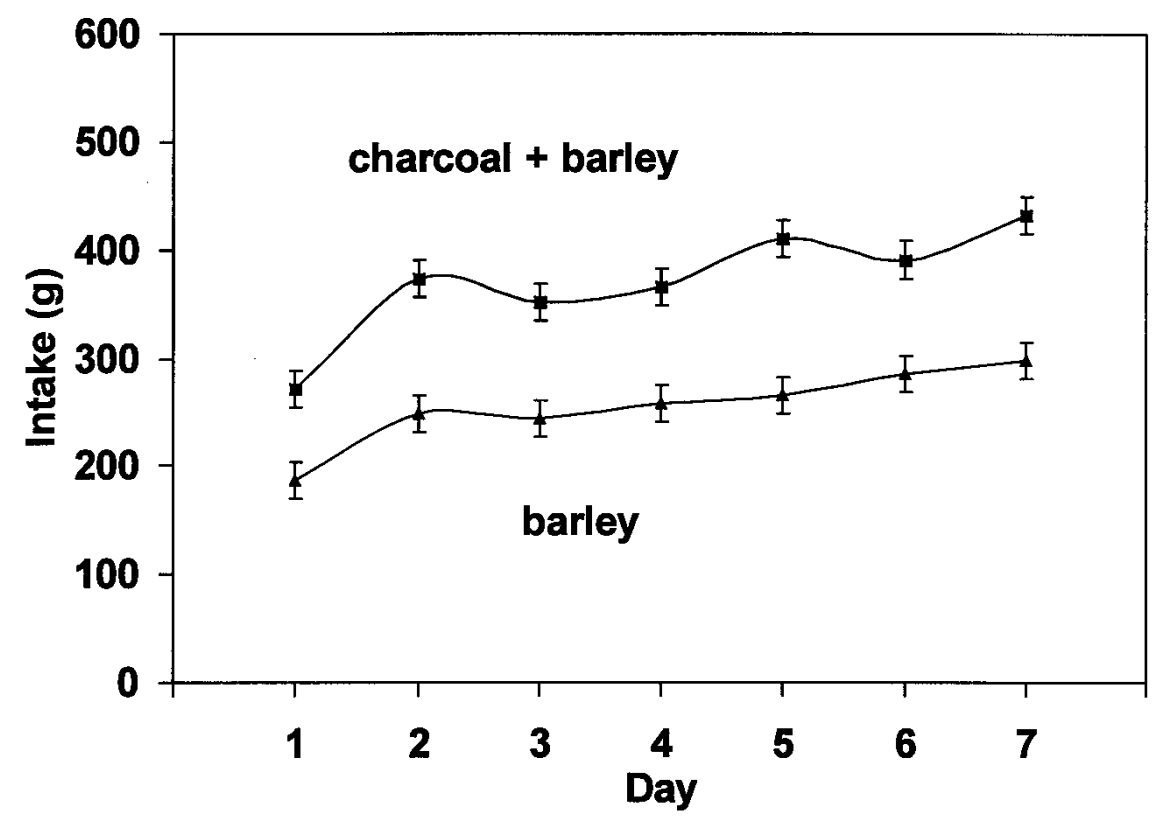

Fig. 3. Intake (means \pm SE) of Artemisia tridentata ssp. tridentata for 4 hours day ${ }^{-1}$ by lambs supplemented with activated charcoal + barley or barley alone (L.S.D. .05 = 33).

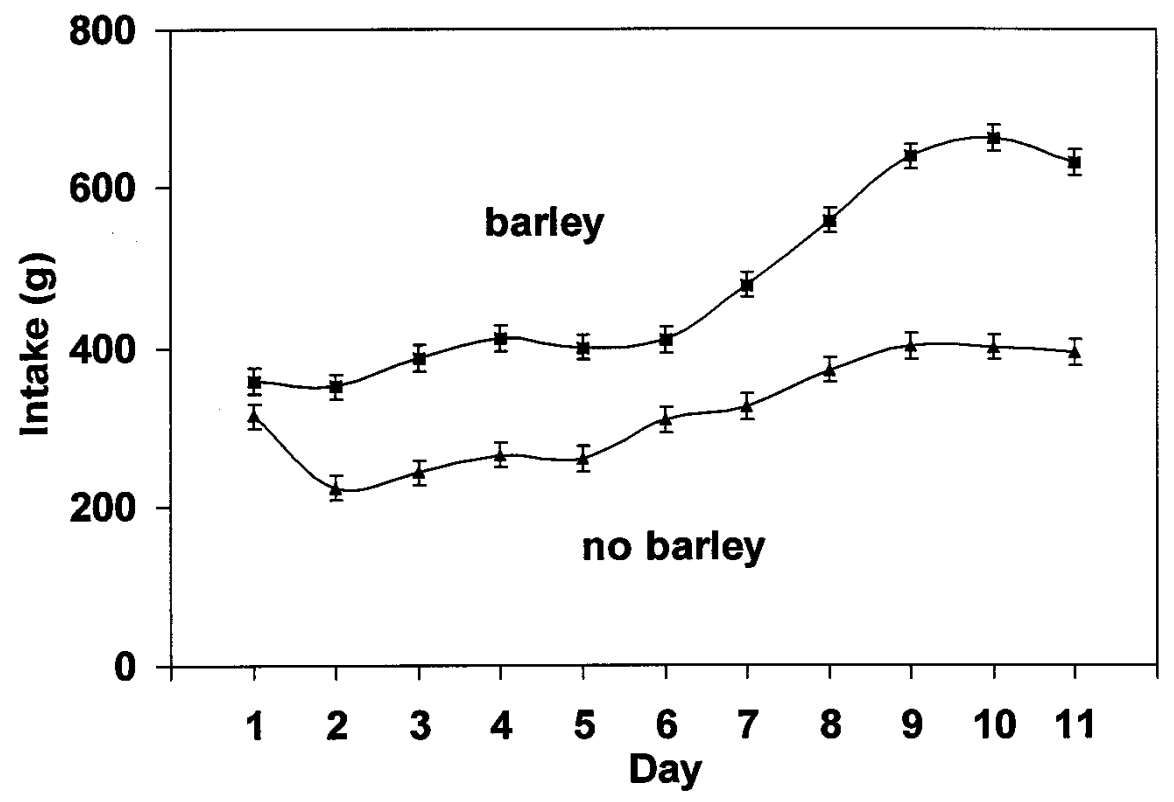

Fig. 4. Intake (means \pm SE) of Artemisia tridentata ssp. vaseyana (days 1 to 3 ) or tridentata (days 4 to 11) for 4 hours day $^{-1}$ by lambs supplemented with barley or not supplemented (L.S.D. .05 = 31).

\section{Experiment 3}

Trial 1. Lambs supplemented with activated charcoal + barley or barley generally ate more $A$. tridentata ssp. vaseyana than lambs not supplemented, and treatment and day interacted ( $\mathrm{P}=.017$; Fig. 5). Lambs fed barley ate a large amount of sagebrush on day 4 , and then decreased intake on days 5 and 6 .

\section{Discussion}

\section{Influence of Supplements}

Lambs supplemented with activated charcoal + barley ate slightly more sagebrush than lambs supplemented with barley, presumably because charcoal adsorbs terpenes in sagebrush. Adsorbents like activated charcoal may be useful for mitigating the aversive postingestive effects of terpenoids. Activated charcoal is used commonly to diminish the effects of poisons and drug overdoses at poison control centers. Administered promptly and in sufficient amounts, activated charcoal appreciably reduces gastrointestinal absorption of toxins, and it also increases clearance of drugs that have been absorbed and are in systemic circulation (Levy 1982).

The influence of supplemental barley was greater than that of charcoal. Most of the increase in intake in Experiment 3 (Trial 2) was accounted for by the addition of barley (Fig. 6). The same pattern is apparent when Trials 1 and 2 (Figs. 2, 3) are compared with Trial 3 (Fig. 4) in Experiment 2. Inadequate nutrition decreases availability of energy and protein, substrates vital in the process of detoxification (McArthur et al. 1991). It is likely that the maximum absorbed allelochemical dose, which will limit the amount of food ingested, depends on the supply of nutrients for detoxification and cosubstrate for conjugation (Glazenberg et al. 1983, Price et al. 1987, Foley et al. 1995, Illius and Jessop 1995, Jessop and Illius 1997, Wang and Provenza 1997). Protein sources high in sulfur-containing amino acids facilitate detoxification of sesquiterpene lactones in bitterweed (Ueckert and Calhoun 1988). Barley is a good source of energy (3.26 Mcal kg-1 DE) and alfalfa is a good source of protein (15 to $17 \% \mathrm{CP}$ ), and barley and alfalfa are both good sources of sulfur-containing amino acids (Nutrient Requirements of Sheep 1985).

\section{Plane of Nutrition}

Our data also suggest that the abundance of an alternative food influenced intake of sagebrush by lambs. During Experiment 3, lambs with access to alfalfa pellets throughout the afternoon (Fig. 5) ate considerably less sagebrush than lambs with only 1 hour access to alfalfa pellets each afternoon (Fig. 6). Lambs fed diets adequate in nutrients avoid foods high in toxins, even when they are supplemented with compounds that ameliorate their effects (e.g., polyethylene glycol and tan- 


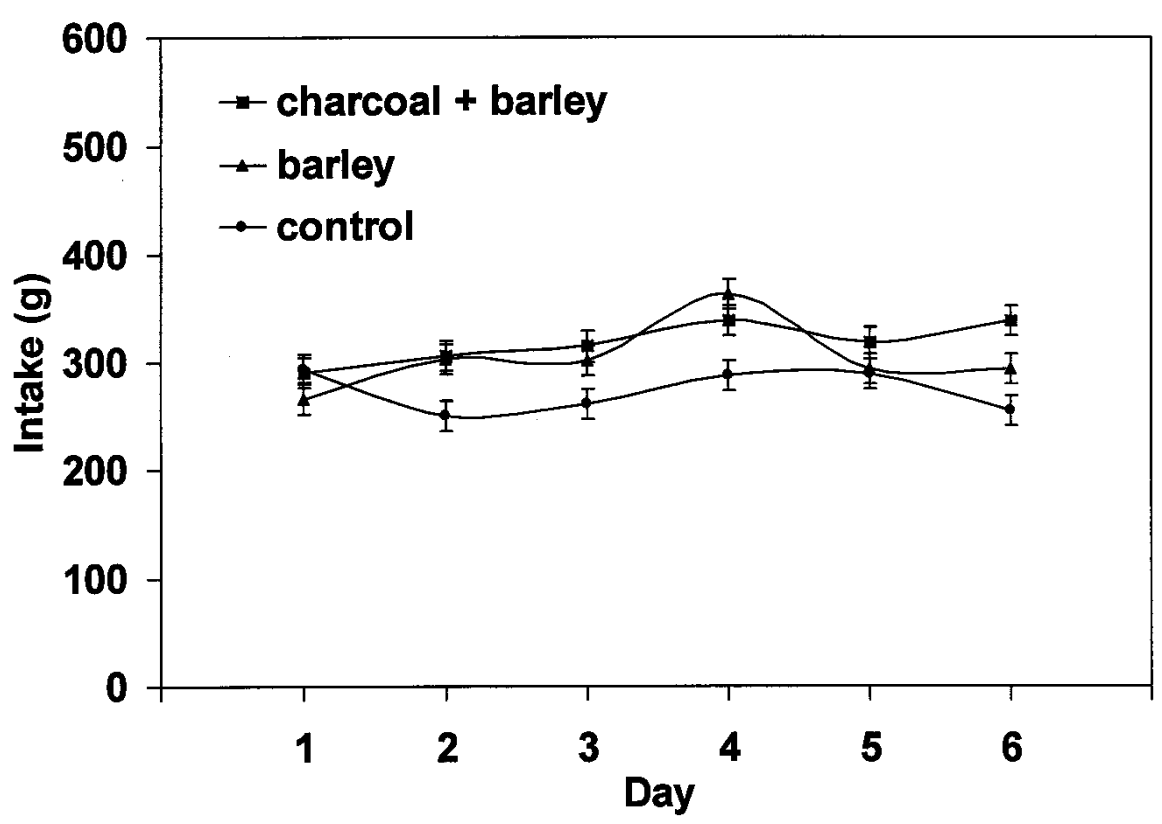

Fig. 5. Intake (means \pm SE) of Artemisia tridentata ssp. vaseyana for 4 hours day $^{-1}$ by lambs supplemented with activated charcoal + barley, barley, or not supplemented. Lambs were fed alfalfa pellets ad libitum in the afternoon during this trial (L.S.D. . .05 $=28$ ).

nins, Titus et al. 1999). The data on food restriction are confounded with the influence of ongoing adaptation to the diet, but they nonetheless warrant further inquiry, particularly into how nutritional quality and abundance of alternative foods influences intake of sagebrush.

In another study, we reported that lambs fed supplemental energy or protein did not increase intake of sagebrush (Burritt et al. 1999). In that study, lambs fed a basal diet inadequate for growth (1.2 times maintenance) also ate more sagebrush than lambs fed a nutritionally adequate diet (2.7 times maintenance). However, both groups of lambs were fed ground sagebrush mixed with barley, and thus benefited from the additional energy provided by the barley. The protein provided by the basal diet of alfalfa pellets fed later in the day likely complemented the supplemental barley to improve sagebrush consumption (Villalba and Provenza 1999, Villalba, unpublished data).

\section{Changes in Intake}

Lambs typically increased intake of sagebrush throughout all three experiments, likely due to ongoing adaptation to the sagebrush diet. The interactions between treatment and day, which occurred in most of our trials, reflect the ongoing divergence in intakes between supplemented and control lambs as trials progressed (Figs. 1, 2, 5). In most cases, supplemented lambs increased intake at a charcoal and barley in Experiment 1 (Fig. 1 , days 7 and 8).

Terpenoids in sagebrush may act as feeding deterrents because they have a bitter flavor or because they are toxic. Sesquiterpene lactones in sagebrush, rubberweeds (Hymenoxys spp.), and orange sneezeweed (Helenium spp.) irritate the mucosa of the mouth and the gastrointestinal tract, which causes vomiting in ruminants (Cheeke and Shull 1985). Sheep limit intake of native hay-sagebrush rations in accord with the concentration of sagebrush (Artemisia tridentata ssp. vaseyana) in the mix (Ngugi et al. 1995). Their dry matter intake decreased from 93 to $23 \mathrm{~g} \mathrm{day}^{-1}$ metabolic body weight ${ }^{-1}$ as sagebrush increased from 0 to $30 \%$ of the ration. These findings are consistent with the idea that the deterrent effects of terpenoids are dose-dependent (Langenheim 1994). The supplement-induced changes in intake in our study suggest that the decrease in intake is at least partially due to the postingestive effects of sagebrush (Provenza 1995).

\section{Implications}

Terpenoids occur in grasses, forbs, shrubs, and trees in all stages of succession from early to late (Picman 1986, Langenheim 1994). Conifers, mints, and euphorbs typically contain terpenoids, and all but one tribe of the family Asteraceae contain sesquiterpene lactones. These plants are often abundant, and could be when we no longer provided activated than lambs not supplemented. However, unsupplemented lambs in Experiment 3 intake from days 1 to 2 (Fig. 5), evidently because they had been supplemented with barley and activated charcoal until day 1 barley and the trial. Rate of intake also declined when we no longer provided activated

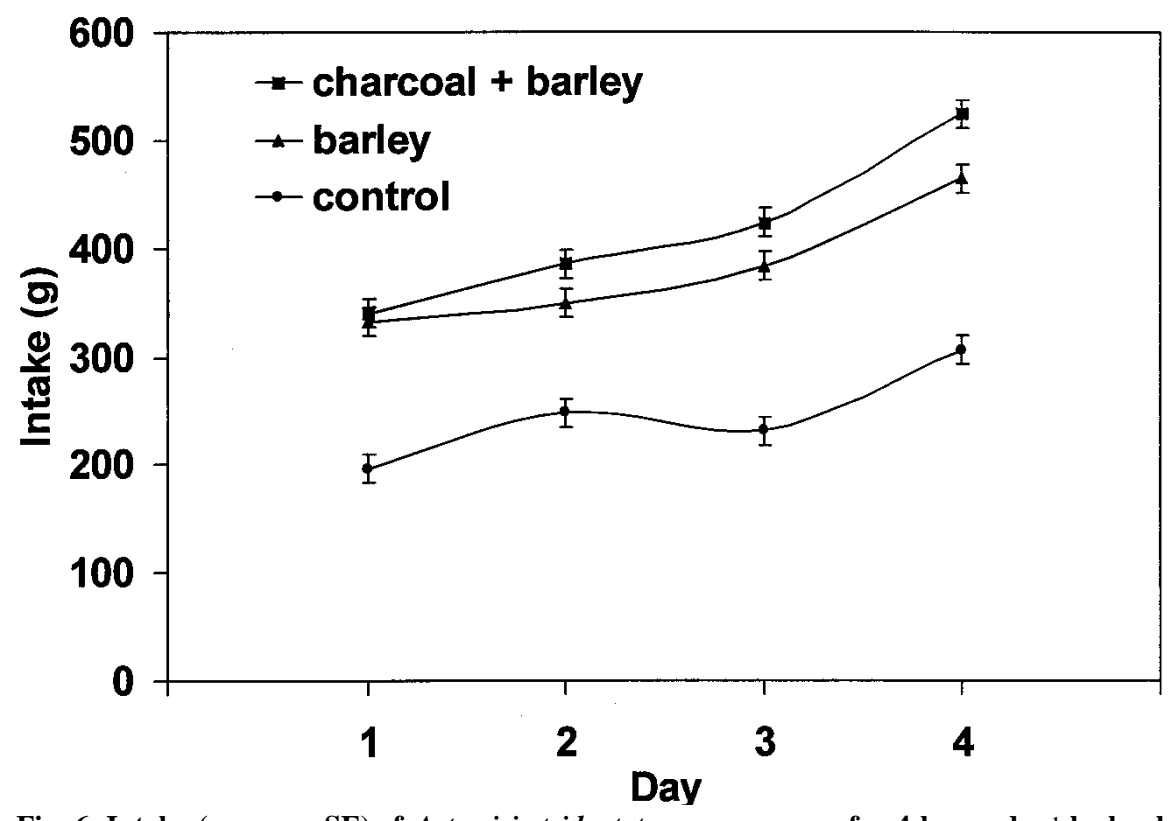

Fig. 6. Intake (means \pm SE) of Artemisia tridentata ssp. vaseyana for 4 hours day $^{-1}$ by lambs supplemented with activated charcoal + barley, barley, or not supplemented. Lambs were fed alfalfa pellets for only 1 hour in the afternoon during this trial (L.S.D. $.05=26$ ). 
important sources of forage for animals in dry environments, but their use is limited by terpenoids.

Managers have used various techniques -herbicides, mechanical manipulations, fire-to reduce the abundance of sagebrush (Bastian et al. 1995). People are skeptical of herbicidal remedies and mechanical manipulations often are not justifiable economically. Fires can cause air quality and safety concerns, even in sparsely populated areas, and it often removes both desirable and undesirable vegetation. Herbivores can reduce the abundance of sagebrush, especially browsing during winter when concentrations of terpenoids are low and sagebrush is most acceptable (Gade and Provenza 1986).

Most accessions of sagebrush are nutritious, but their nutritive value may be offset by the deleterious effects of terpenoids (Ngugi et al. 1995). Sheep supplemented with adsorbents and macronutrients eat more sagebrush than non-supplemented sheep under confined conditions. Thus, it is important to determine if supplementation will also influence sheep to eat more sagebrush on rangelands during fall and winter. The coincidental timing of sagebrush acceptability and flushing ewes for reproduction may provide a practical opportunity to increase use of sagebrush by sheep. Supplementing ewes to improve conception during breeding and utilizing sagebrush when it is lower in terpenoids may be a practical management solution. Likewise, supplementing sheep and cattle with macronutrient-rich concentrates, as opposed to poorer quality roughages, may enhance intake of sagebrush during fall and winter.

Several benefits could be realized if herbivores used sagebrush more. For example, the abundance of sagebrush might be reduced because sagebrush does not tolerate grazing well (Bilbrough and Richards 1993). Increasing use of sagebrush, and decreasing use of alternate forages, would likely enhance production of grasses and forbs and create a more diverse mix of plants. In addition, the amount of forage in the western United States would increase substantially if domestic and wild herbivores used sagebrush. Herbivores might use sagebrush steppe uplands more, and riparian areas less, if their preference for sagebrush were to increase. Use of livestock browsing to reduce biomass of shrubs and trees in areas prone to fire also depends on how terpenoids affect preference. Finally, the results may apply broadly, as 15,000 to 20,000 terpenoids have been identified from plants worldwide. However, it is important to note that the effectiveness of macronutrient supplements and activated charcoal will likely vary with the chemical structure of the terpenoid.

\section{Literature Cited}

Bastian, C.T., J.J. Jacobs, and M.A. Smith. 1995. How much sagebrush is too much: An economic threshold analysis. J. Range Manage. 48:73-80.

Bilbrough, C.J. and J.H. Richards. 1993. Growth of sagebrush and bitterbrush following simulated winter browsing: Mechanisms and tolerance. Ecol. 74:481-492.

Bray, R.O., C.L. Wambolt, and R.G. Kelsey. 1991. Influence of sagebrush terpenoids on mule deer preference. J. Chem. Ecol. 17:2053-2062

Burritt, E.A., R.E. Banner, and F.D. Provenza. 2000. Effects of experience and macronutrients on ingestion of sagebrush (Artemisia tridentata subsp. vaseyana) by lambs. J. Range Manage. 53:91-96.

Cheeke, P.R. and L.R. Shull. 1985. Natural Toxicants in Feeds and Poisonous Plants. AVI Publ. Co., Westport, Conn.

Foley, W.J., S. McLean, and S.J. Cork. 1995. Consequences of biotransformation of plant secondary metabolites on acid-base metabolism in mammals-A final common pathway? J. Chem. Ecol. 21:721-743.

Gade, A.E. and F.D. Provenza. 1986. Nutrition of sheep grazing crested wheatgrass versus crested wheatgrass shrub pastures during winter. J. Range Manage. 39:527-530.

Glazenberg, E.L., I.N.C. Jekel-Halsema, E. Scholtens, A.J. Baars, and G.J. Mulder. 1983. Effects of variation in the dietary supply of cysteine and methionine on liver concentration of glutathione and active sulfate (PAPS) and serum levels of sulphate, cystine, methionine and taurine: relations to the metabolism of acetaminophen. J. Nutr. 113:1363-1373.

Hayden, J.W. and E.G. Comstock. 1975. Use of activated charcoal in acute poisoning. Clin. Toxicol. 8:515-533.

Illius, A.W. and N.S. Jessop. 1995. Modeling metabolic costs of allelochemical ingestion by foraging herbivores. J. Chem. Ecol. 21:693-719.

Jessop, N.S. and A.W. Illius. 1997. Modeling animal responses to plant toxicants, $\mathrm{p}$. 243-253. In: J.P. Felix D'Mello (ed.), Plant and Fungal Toxicants. CRC Press Inc., Boca Raton, Fla.

Johnson, A.E., L.F. James, and J. Spillet. 1976. The abortifacient and toxic effects of big sagebrush (Artemisia tridentata) and juniper (Juniperus osteosperma) on domestic sheep. J. Range Manage. 29:278-280.

Langenheim, J.H. 1994. Higher plant terpenoids: A phytocentric overview of their ecological roles. J. Chem. Ecol. 20:1223-1280.
Levy, G. 1982. Gastrointestinal clearance of drugs with activated charcoal. N. Engl. J. Med. 307:676-678.

McArthur, C., A.E. Hagerman, and C.T. Robbins. 1991. Physiological strategies of mammalian herbivores against plant defenses, p. 103-114. In: R.T. Palo and C.T. Robins (eds.), Plant Defenses Against Mammalian Herbivory. CRC Press Inc., Boca Raton, Fla.

Ngugi, R.K., F.C. Hinds, and J. Powell. 1995. Mountain big sagebrush decreases dry matter intake, digestibility, and nutritive quality of sheep diets. J. Range Manage. 48:487-492.

Nutrient Requirements of Sheep. 1985. National Academy Press, Washington, D.C.

Personius, T.L., C.L. Wambolt, J.R. Stephens, and R.G. Kelsey. 1987. Crude terpenoid influence on mule deer preference for sagebrush. J. Range Manage. 40:84-88.

Picman, A.K. 1986. Biological activities of sesquiterpene lactones. Biochem. Syst. Ecol. 14:255-281.

Price, V.F., M.G. Miller, and D.J. Jollow. 1987. Mechanisms of fasting-induced potentiation of acetaminophen hepato toxicity in the rat. Biochem. Pharmacol. 36:427-433.

Provenza, F.D. 1995. Postingestive feedback as an elemental determinant of food preference and intake in ruminants. J. Range Manage. 48:2-17.

Titus, C.H., F.D. Provenza, E.A. Burritt, A. Perevolotsky, and N. Silanikove. 2000. Preferences for foods varying in macronutrients and tannins by lambs supplemented with polyethylene glycol. J. Anim. Sci. (In Press).

Ueckert, D.N. and M.C. Calhoun. 1988. Ecology and toxicology of bitterweed (Hymenoxys odorata). In: L.F. James, M.H. Ralphs and D.B. Nielson (eds.), The Ecology and Economic Impact of Poisonous Plants on Livestock Production. Westview Press, Boulder, Colo.

Villalba, J.J. and F.D. Provenza. 1999. Nutrient-specific preferences by lambs conditioned with intraruminal infusions of starch, casein, and water. J. Anim. Sci. 77:378-387.

Wang, J. and F.D. Provenza. 1997. Dynamics of preference by sheep offered foods varying in flavors, nutrients, and a toxin. J. Chem. Ecol. 23:275-288.

Welch, B.L. and J.C. Pederson. 1981. In vitro digestibility among accessions of big sagebrush by mule deer and its relationship to monoterpenoid content. J. Range Manage. 34:497-500.

Welch, B.L. and E.D. McArthur. 1986. Wintering mule deer preference for 21 accessions of big sagebrush. Great Basin Natur. 46:281-286. 